\title{
EFFECT OF LOW-DOSE ZEARALENONE EXPOSURE ON LUTEAL FUNCTION, FOLLICULAR ACTIVITY AND UTERINE OEDEMA IN CYCLING MARES
}

\author{
Judit JuhÁsz ${ }^{1}$, P. NAGY ${ }^{2}$, Margit KulCSÁR ${ }^{2}$, G. SZIGETI $^{4}$, J. REICZIGEL ${ }^{3}$ \\ and GY. HUSZENICZA ${ }^{2 *}$ \\ ${ }^{1}$ Research Institute, ${ }^{2}$ Department of Obstetrics and Reproduction, ${ }^{3}$ Department \\ of Biomathematics, Faculty of Veterinary Science, Szent István University, H-1400 \\ Budapest, P.O. Box 2, Hungary; ${ }^{4}$ Central Veterinary Institute, Budapest, Hungary
}

(Received September 15, 2000; accepted February 8, 2001)

The effect of 10-day zearalenone administration starting 10 days after ovulation was studied in 6 cycling trotter mares in the summer period. After an entire oestrous cycle (Cycle 1), mares were given $7 \mathrm{mg}$ purified zearalenone per os daily $(1 \mathrm{mg} / \mathrm{ml}$ in ethyl alcohol) beginning on Day 10 of Cycle 2 . Toxin exposure was continued until the subsequent ovulation. Luteal function and follicular activity were monitored daily by rectal palpation, ultrasonography and blood sampling for progesterone. During toxin exposure, all animals were in good physical condition. The toxin had no effect on the length of the interovulatory intervals, luteal and follicular phases. It did not influence significantly the plasma progesterone profiles (logistic curve parameters A1 to A6), the follicular activity (growth rate, maximum size of the ovulatory follicles, maximum number and the time of first increase in the number of large follicles) and the uterine oedema. It is concluded that in cyclic mares the methods used in this study could not detect any adverse effect of zearalenone (administered at a low dose similar to natural exposure) on reproduction. oedema

Key words: Mare, zearalenone, progesterone, follicular activity, uterine

Reproductive efficiency in horses may be influenced by several factors including mycotoxins occurring as feed contaminants. In the practice, reproductive problems of mares such as late resumption of cyclic ovarian activity, prolonged corpus luteum function, decreased per cycle fertility rate and increased early embryonic mortality are often explained by some, not precisely specified nutritional factors. Despite this fact, however, mycotoxin-induced genital malfunctions have received little attention in this species (Juhász et al., 1997).

Mycotoxins are produced by moulds growing in crops and stored feed. Zearalenone, a $\beta$-resorcylic acid lactone is produced by many species of Fusar-

*Corresponding author; E-mail: gyhuszen@univet.hu; Fax: +36 (1) 478-4207 
ium, primarily $F$. graminearum and $F$. culmorum, and it is a natural contaminant of corn, wheat, barley, oat and hay (Coulombe, 1993; Oldenburg et al., 2000). Despite structural dissimilarity to steroidal oestrogens, zearalenone has oestrogenic properties (Katzenellenbogen et al., 1979; Blankenship et al., 1982) and, thus, exerts a detrimental effect on the reproductive performance of pigs. In mature, nonbred sows zearalenone exposure may result in constant oestrus, ovarian atrophy, pseudopregnancy, uterine hyperplasia, metaplasia of the cervical epithelia and oedema of the mammary gland (Kurtz et al., 1969; Edwards et al., 1987; Ványi et al., 1995). A large proportion of gilts (40-90\%) fed low levels of zearalenone did not return to oestrus for a period of 50 to 80 days and mycotoxin-induced retention of corpora lutea was similar to that occurring when sows are given exogenous oestrogen on days 11-12 of the oestrous cycle (Etienne and Jemmali, 1982; Young and King, 1986; Diekman and Green, 1992). In other domestic species, reproductive problems related to zearalenone exposure have been less frequently described. In cows, decreased fertility, reduced milk production, swollen and hyperaemic external genitalia and enlarged mammary glands (Mirocha et al., 1968; Ványi et al., 1974; Bloomquist et al., 1982; Weaver et al., 1986; Huszenicza et al., 1995), in ewes, decline in ovulation rate and increase in duration of oestrus (Smith et al., 1990), while in horses the lack of oestrus (Kallela and Ettala, 1984) have been reported.

The mechanism of the oestrogenic effect of zearalenone appears to be mediated via binding of the mycotoxin and its metabolites to cytoplasmic oestrogen receptors (Katzenellenbogen et al., 1979). In horses, oestrogens have several important physiological roles. They are responsible for the expression of oestrous behaviour (Nett, 1993). Oestrogens secreted by the developing conceptus may play a role in the maternal recognition of pregnancy (Zavy et al., 1984). This idea is supported by earlier findings demonstrating that administration of oestrogen to nonbred mares resulted in prolonged interovulatory interval (Berg and Ginther, 1978). The increase in interovulatory interval after oestrogen administration may be the result of suppressed follicular development and not of a failure of corpus luteum regression (Woodley et al., 1979).

The objective of the present study was to test the hypothesis that zearalenone as an oestrogenic compound administered at low dose starting 10 days after ovulation affects corpus luteum function, follicular development and uterine oedema in cyclic mares.

\section{Materials and methods}

\section{Animals and toxin exposure}

Six trotter mares, aged 6-14 years and weighing 530-650 kg, were included in the experiment, which was carried out in early summer during two oestrous cycles (Cycle 1 and Cycle 2). Mares were kept together in an open barn 
during the night and let out to graze during the day. They were fed hay ad libitum and $2 \mathrm{~kg}$ of oats with no detectable amount of zearalenone either twice daily before toxin exposure, or once daily during toxin exposure. All of them maintained good body condition throughout the study.

Zearalenone ( $>95 \%$ of purity) was produced on corn substrate $(5000 \mathrm{mg} / \mathrm{kg})$ using strains of Fusarium graminearum (MC 71053). The extraction and purification of toxin was carried out according to Christensen et al. (1965). The purified toxin was dissolved in $30 \%$ ethyl alcohol to give a solution containing $1 \mathrm{mg} / \mathrm{ml}$ of zearalenone. Each mare was given $7 \mathrm{mg}$ zearalenone per day in the morning feed. This ration was prepared the previous afternoon. The oats containing the toxin was given to the mares individually and special attention was paid so that all the mares ate the entire amount. Body temperature was taken each morning before the reproductive examinations.

Mares were followed but not treated for one complete oestrous cycle (Cycle 1) and toxin exposure was started on Day 10 after ovulation (Day 0) in the next cycle (Cycle 2) and was continued until subsequent ovulation.

\section{Ovarian follicular dynamics and uterine changes}

Rectal examination and ultrasonography of the ovaries and uterus, using a real-time linear array scanner (Aloka SS-210 DX, ALOKA Inc., Japan) with a $5 \mathrm{MHz}$ rectal probe, were carried out daily throughout the study. Follicular activity and other parameters such as uterine and cervical tone and turgidity, presence and extent of uterine oedema and the size and quality of the corpus luteum, were also recorded. The diameter of all follicles larger than $1 \mathrm{~cm}$ were measured using the electronic callipers of the scanner on frozen screen. The diameter was defined as the longest dimension of the antrum of a spherical follicle. In case of non-spherical follicle, both the longest and the widest dimensions were recorded and the two values averaged. Follicles were counted and classified according to size (small: $1-2 \mathrm{~cm}$ and large: $>2 \mathrm{~cm}$ ). The maximum number of follicles $(>1 \mathrm{~cm})$, the maximum number of large follicles, the time of first increase in the number of large follicles and the growth rate and maximum size of the ovulatory follicles were used as endpoints for statistical analysis. Uterine oedema was recorded using a scoring system from 0 to 3 . Score 0 represented dioestrus-like uterus with ultrasonically homogenous uterine echotexture. Score 1 to 3 indicated oestrus-like uterus at different levels. During oestrus, alternating and intertwining echogenic and nonechogenic areas resulted in the so-called 'lemon or wheel' shape uterine echotexture. Score 0.5 represented transition between dioestrus- and oestrus-like echotextures. 


\section{Blood sampling and progesterone assay}

Blood samples were collected daily at the time of examinations by jugular venipuncture into heparinised tubes. Samples were centrifuged shortly after collection for $10 \mathrm{~min}$ at $3000 \mathrm{rpm}$ before plasma was harvested. Plasma samples were then stored at $-20^{\circ} \mathrm{C}$ until assayed for progesterone.

Progesterone was measured using a nonextraction, liquid-phase tritiumbased radioimmunoassay validated for equine plasma (Nagy et al., 1998). The antiserum used is highly specific for progesterone and $11 \alpha-\mathrm{OH}$-progesterone $(96 \%)$ and it shows particularly low cross-reactivity with other progestagens $(0.0001 \%-0.6 \%$; Csernus, 1982). The intra- and interassay coefficient of variations for plasma pools representing low (3-4 nmol/l), medium $(6-7 \mathrm{nmol} /)$ and high (15-19 nmol/l) ranges were $15.4 \%, 7.6 \%, 8.0 \%$ and $13.0 \%, 9.7 \%, 7.3 \%$, respectively.

\section{Statistical analysis}

The length of the interovulatory intervals, oestrous and dioestrous periods were determined. The length of the luteal phase was defined as the time from ovulation until the subsequent decline of plasma progesterone concentration to $1 \mathrm{nmol} / \mathrm{l}$. The follicular phase was defined as the period from when plasma progesterone concentration first fell below $1 \mathrm{nmol} / 1$ until ovulation. Changes in these parameters in Cycle 2 (mycotoxin exposure) compared to Cycle 1 (control cycle) were evaluated using paired $t$-test.

Biphasic logistical curves $\left(\mathrm{P} 4=\mathrm{A} 1\left[1+\mathrm{e}^{-\mathrm{A} 2(\mathrm{t}-\mathrm{A} 3)}\right]^{-1}-\mathrm{A} 4\left[1+\mathrm{e}^{-\mathrm{A} 5(\mathrm{t}-\mathrm{A} 6)}\right]^{-1}\right.$, $\mathrm{P} 4=$ plasma progesterone, $\mathrm{t}=$ day of cycle, $\mathrm{A} 1$ to $\mathrm{A} 6=$ curve parameters) were fitted to the progesterone profile of each interovulatory interval by the DUD method of NLIN procedure of SAS data analysis system. A1 and A4 represent the upper asymptotic values of the progesterone for the two curves. A3 and A6 are the locations of the inflection points and $\mathrm{A} 2$ and $\mathrm{A} 5$ are proportional to the slope of the curves at the inflection points (slope $=-\mathrm{A} 1 \mathrm{~A} 2 \mathrm{~A} 3 / 4$ and $-\mathrm{A} 4 \mathrm{~A} 5 \mathrm{~A} 6 / 4$ ) (Koops, 1986). To test the effect of toxin exposure on plasma progesterone secretion, the parameters of the progesterone profiles calculated from Cycle 2 were compared to those of Cycle 1 by paired $t$-test.

For the analysis of follicular activity and uterine oedema, data were adjusted to the end of the oestrous cycle. The growth rate of the largest follicles during oestrus was calculated by linear regression of the follicular diameter over the days of cycle (slope = growth rate, Sirois et al., 1989). The characteristics of follicular activity (first increase in the number of large follicles, maximum number of all $(>1 \mathrm{~cm})$ and large follicles $(>2 \mathrm{~cm})$, growth rate and maximum size of the ovulatory follicles) and uterine oedema (first increase in uterine echotexture $\geq$ score 1 , maximum uterine score) during the control (Cycle 1) and mycotoxintreated (Cycle 2) cycles were also compared using paired $t$-test. 


\section{Results}

The toxin exposure lasted 8 to 10 days depending on the length of the oestrous cycles exhibited by the individual mares. During toxin administration, all animals were in good physical condition and none of them developed systemic signs of distress. Body temperatures always remained within the physiological range.

The toxin had no effect on the interovulatory intervals, or on the lengths of luteal and follicular phases (Fig. 1). The mean ( \pm SEM) interovulatory interval and length of dioestrous and oestrous periods were $19.3( \pm 0.76), 12.5( \pm 0.56)$ and $6.8( \pm 0.48)$ days, respectively in Cycle 1. There were no significant changes $(\mathrm{P}>0.1)$ in these parameters observed during mycotoxin exposure $(18.3 \pm 0.42$, $12.5 \pm 0.22$ and $5.8 \pm 0.31$ days, respectively).

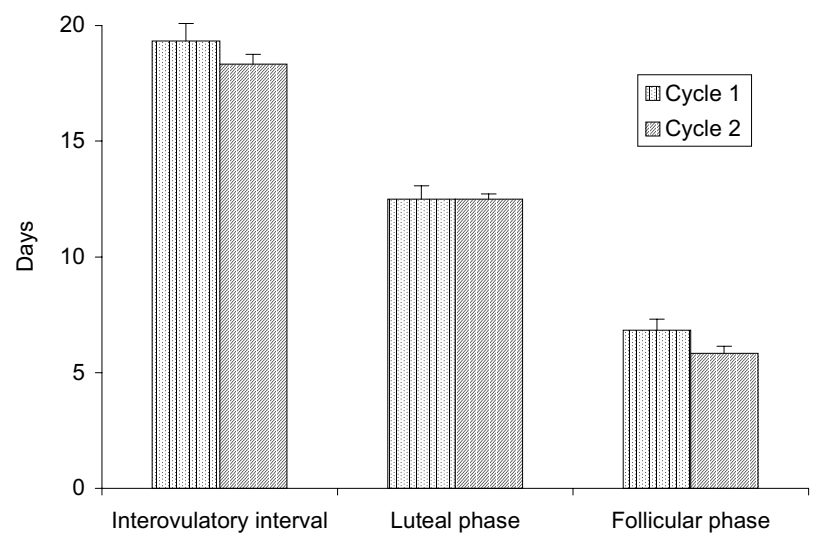

Fig. 1. Comparison of the length of the interovulatory intervals, luteal and follicular phases in the control (Cycle 1) and mycotoxin-treated (Cycle 2) cycles. Error bars represent standard error of mean. There was no toxin exposure in Cycle 1, it was started on Day 10 of Cycle 2 and was continued until ovulation

Using the biphasic logistical curve-fitting model, individual progesterone profiles were described accurately. There was a close relationship between measured and calculated values $(\mathrm{R}=0.98)$. Figure 2 shows the measured and calculated progesterone profiles of a representative mare, together with the final growth of the ovulatory follicles, throughout the study. The means of the different curve parameters in the control and mycotoxin-treated cycles are shown in Table 1. There was no significant difference in these curve parameters between Cycles 1 and $2(\mathrm{P}>0.1)$. Exposure of zearalenone did not influence maximum plasma progesterone concentration, the time of luteolysis and the rate of decrease in progesterone during luteolysis. 


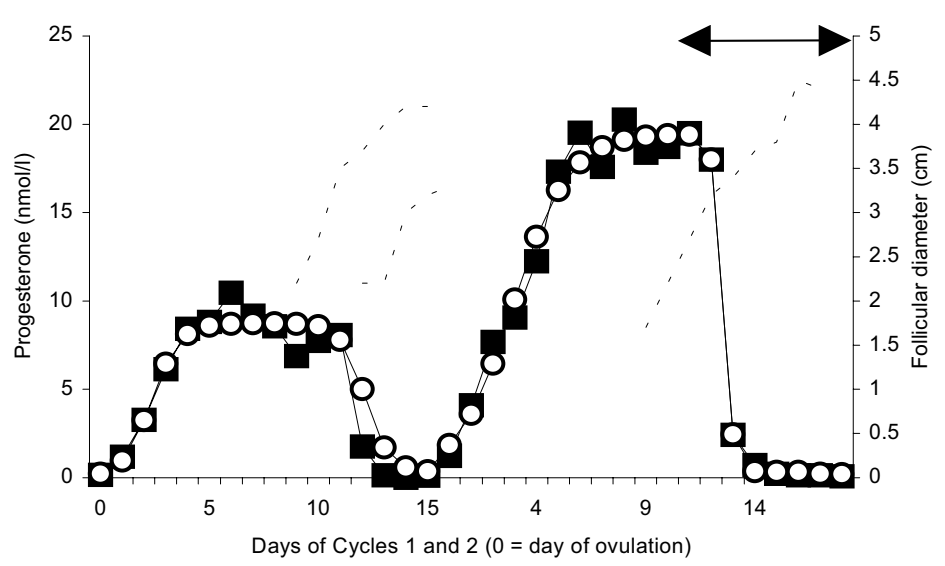

Fig. 2. Measured ( $\bullet$ ) and calculated (०) plasma progesterone profiles and final growth of the ovulatory follicles (dotted lines) of a representative mare throughout the study. The arrow shows the period of toxin exposure (from Day 10 of Cycle 1 until ovulation). Note increased plasma progesterone concentration in Cycle 2 after double ovulation

Table 1

The characteristics (parameter A1 to A6) of calculated plasma progesterone profiles in the control (Cycle 1) and mycotoxin-treated (Cycle 2) cycles

\begin{tabular}{lcccccc}
\hline & $\begin{array}{c}\text { A1 } \\
\text { mean } \\
( \pm \text { SEM })\end{array}$ & $\begin{array}{c}\text { A2 } \\
\text { mean } \\
( \pm \text { SEM })\end{array}$ & $\begin{array}{c}\text { A3 } \\
( \pm \text { SEM })\end{array}$ & $\begin{array}{c}\text { A4 } \\
\text { mean } \\
( \pm \text { SEM })\end{array}$ & $\begin{array}{c}\text { A5 } \\
\text { mean } \\
( \pm \text { SEM })\end{array}$ & $\begin{array}{c}\text { A6 } \\
\text { mean } \\
( \pm \text { SEM })\end{array}$ \\
\hline Cycle 1 & 14.5 & -1.2 & -3.2 & 14.7 & -2.0 & -13.1 \\
& $(1.75)$ & $(0.19)$ & $(0.53)$ & $(1.82)$ & $(0.50)$ & $(0.59)$ \\
\hline Cycle 2 & 14.4 & -1.2 & -2.5 & 14.4 & -1.9 & -20.5 \\
& $(1.22)$ & $(0.16)$ & $(0.16)$ & $(1.30)$ & $(0.65)$ & $(7.75)$ \\
\hline
\end{tabular}

Of the 12 oestrous cycles monitored, 9 (75\%) showed single ovulation and $3(25 \%)$ double ovulation. One double ovulation occurred in the control cycles and 2 during toxin exposure. The characteristics of follicular development during the control and mycotoxin-treated cycles are shown in Table 2. The maximum number of follicles $(>1 \mathrm{~cm})$ was significantly higher in Cycle 2 compared to $\mathrm{Cy}-$ cle $1(\mathrm{P}<0.05)$. There was no difference in the other parameters. The first increase in the number of large follicles $(>2 \mathrm{~cm})$ occurred 9 to 10 days before ovulation. The mean maximum number of these follicles was 3-3.7. Changes in the mean number of large follicles, showed similar pattern in the control (Cycle 1) and mycotoxin-treated (Cycle 2) cycles (Fig. 3). The maximum size of the preovulatory follicles $(4.2-4.3 \mathrm{~cm})$ and their growth rate $(3.1-3.2 \mathrm{~mm} /$ day $)$ were similar between the cycles. 
Table 2

The characteristics of follicular activity and uterine oedema in the control (Cycle 1) and mycotoxin-treated (Cycle 2) cycles

\begin{tabular}{lrr}
\hline & $\begin{array}{c}\text { Cycle 1 } \\
\text { Mean }( \pm \text { SEM) }\end{array}$ & $\begin{array}{c}\text { Cycle 2 } \\
\text { Mean }( \pm \text { SEM })\end{array}$ \\
\hline $\begin{array}{l}\text { 1st increase in the number of large follicles } \\
(>2 \mathrm{~cm} \text {, day before ovulation) }\end{array}$ & $-9.0(1.86)$ & $-9.7(1.69)$ \\
$\begin{array}{l}\text { Maximum number of large follicles }(>2 \mathrm{~cm}) \\
\text { Maximum number of follicles }(>1 \mathrm{~cm})\end{array}$ & $3.0(0.86)$ & $3.7(0.56)$ \\
\hline Ovulatory follicle & $8.2^{\mathrm{a}}(0.95)$ & $12.0^{\mathrm{b}}(1.61)$ \\
$\quad$ & & $3.1(0.20)$ \\
$\quad$ Growth rate (mm/day) & $3.2(0.19)$ & \\
$\quad$ Maximum size (cm) & $4.2(0.03)$ & \\
\hline Uterine oedema & & $-4.0(0.37)$ \\
$\quad \begin{array}{l}\text { 1st increase in uterine score } \geq 1 \\
\quad \text { day before ovulation) }\end{array}$ & $-5.2(0.60)$ & $1.9(0.08)$ \\
$\quad$ Maximum uterine score & $2.0(0.00)$ & \\
\hline
\end{tabular}

Values in the same row with different superscripts are different at $\mathrm{P}<0.05$ level

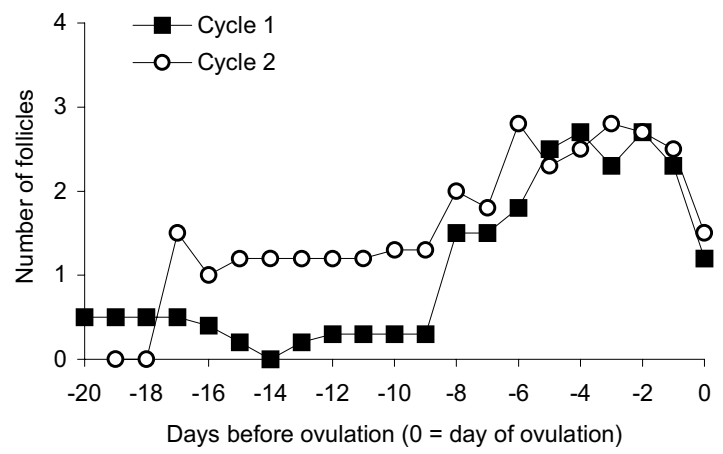

Fig. 3. Changes in the mean number of large follicles $(>2 \mathrm{~cm})$ in the control (Cycle 1) and mycotoxin-treated (Cycle 2) cycles. Data are adjusted to the time of ovulation

There was a gradual increase in uterine echotexture representing uterine oedema from 6 to 8 days until 2 days before ovulation followed by a sharp decrease until ovulation both in the control and mycotoxin-treated cycles (Fig. 4). Exposure of zearalenone had no significant effect $(\mathrm{P}>0.1)$ on the time of first increased uterine echotexture (uterine score $\geq 1 ; 4-5.2$ days before ovulation) 
and on maximum uterine echotexture (scale from 0 to 3; uterine score: 1.9-2; Table 2). There was no abnormal oestrous behaviour and pathologically swollen and hyperaemic external genitalia observed during zearalenone exposure.

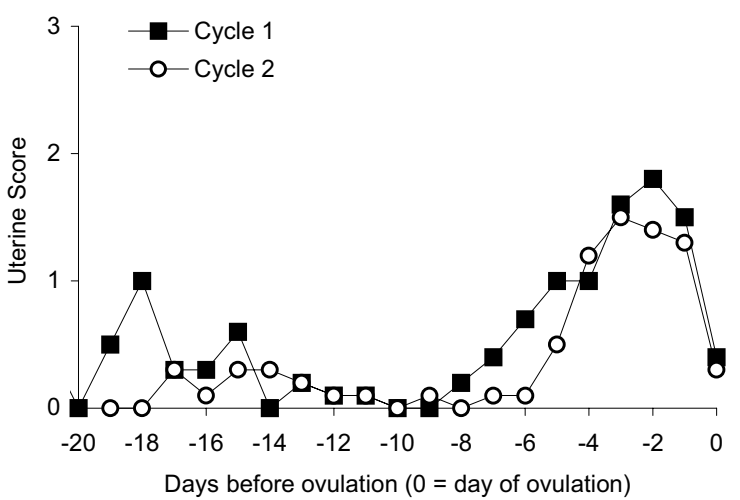

Fig. 4. Changes in uterine echotexture (Score 0 to 3 ) representing uterine oedema in the control (Cycle 1) and mycotoxin-treated (Cycle 2) cycles. Data are adjusted to the time of ovulation

\section{Discussion}

In our experiment, we tested the hypothesis that zearalenone, a feedcontaminant mycotoxin administered at low dose starting 10 days after ovulation affects corpus luteum function, follicular development and uterine oedema in cyclic mares. As in other domestic species, zearalenone, together with other mycotoxins could have a role in the development of reproductive disturbances such as prolonged corpus luteum function, decreased fertility and increased early embryonic mortality that are frequently encountered problems on stud farms. In our model, we wanted to simulate an increased natural toxin exposure. Mares usually consume around $7 \mathrm{~kg}$ of feed per day and $1 \mathrm{mg} / \mathrm{kg}$ feed toxin concentration can occur as natural contamination in crops (Pier et al., 1980; Oldenburg et al., 2000). For this reason, mares were administered $7 \mathrm{mg}$ purified zearalenone mixed with the morning ration.

In the study, no contemporary controls were used but control and treated cycles were compared in each mare. We used a 2-stage method to analyse our results. In the first stage, summary measures (logistic curve parameters, growth rate and maximum size of ovulatory follicle, etc.) were extracted from our serial measurements (daily plasma progesterone concentrations, number of follicles, diameters of the ovulatory follicles, score of uterine oedema). In the second part, these summary measures were compared by a simple statistical method of the paired $t$-test (Matthews et al., 1990). The arbitrary classification of follicles 
(small follicle: 1 to $2 \mathrm{~cm}$ in diameter, large follicle: $>2 \mathrm{~cm}$ ) was based on studies demonstrating that the diameters of the two large follicles at the beginning of deviation are 2.2 and $1.9 \mathrm{~cm}$ (Ginther, 2000).

We have shown that zearalenone administered at low dose starting 10 days after ovulation did not influence the interovulatory interval, the length of luteal and follicular phases, plasma progesterone concentration, the rate of decrease in progesterone during luteolysis, the first increase in the number of large follicles $(>2 \mathrm{~cm})$, their maximum number, the growth rate and maximum size of the preovulatory follicles, and uterine oedema. For this reason, our hypothesis was rejected. The significant increase in the maximum number of follicles $(>1 \mathrm{~cm})$ during Cycle 2 was not related to toxin exposure since it occurred before zearalenone administration was started.

There could be several reasons why we have not observed any reproductive effect of zearalenone in our study. The oestrogenic effect of zearalenone is influenced by several factors such as (1) the sensitivity of the species, (2) the age of the animal, (3) the reproductive stage and (4) the dose. Most probably, the relationship among these factors determines whether the oestrogenic effect of zearalenone is manifested in a specific case. The sensitivity of a species seems to be related to the relative binding affinity of the toxin to oestrogen receptors and its in vivo metabolism. Zearalenone has a greater affinity for oestrogen receptors from animals that are more susceptible to the oestrogenic effects of the mycotoxin (Coulombe, 1993). There is also species variation in the metabolism of zearalenone concerning metabolites ( $\alpha$ - or $\beta$-zearalenol) and conjugates (glucuronic or sulphate) that have different relative binding affinity for oestrogen receptors (Lindsay, 1985; Olsen et al., 1985). In horses, there are no data available on the metabolism and the binding affinity of zearalenone and its metabolites. Young, prepubertal animals seem to be more sensitive to zearalenone than adults. It is well known that prepubertal gilts are the most sensitive to the toxin but no reproductive effect is observed at levels below $0.5 \mathrm{mg} / \mathrm{kg}$ feed (Kurtz et al., 1969; Friend et al., 1990). Whereas, in mature gilts the reproductive no-effect level is higher, around 3.5-4 mg/kg feed (Etienne and Jemmali, 1982; Young and King, 1986). Interestingly, cyclic animals seem to be more sensitive than pregnant sows. Higher doses ( $>60 \mathrm{mg} / \mathrm{kg}$ feed) are required to affect embryonic development (Long et al., 1982; Long and Diekman, 1984). Above a certain level of toxin exposure, there is a linear relationship between the dose and the frequency of reproductive disturbances. In ewes, there is a linear decline in ovulation rate, length of the cycle and increase in oestrus duration with increasing dose level (Smith et al., 1990). In pregnant sows, the frequency of decreased litter size is increasing with the dose (Long et al., 1982).

Based on our results, it seems that the dose applied in our study ( $7 \mathrm{mg} /$ animal $\approx 1 \mathrm{mg} / \mathrm{kg}$ feed) was below the reproductive no-effect level of adult, cyclic mares. Most probably, we could have induced some reproductive 
disturbances using higher doses ( $>10 \mathrm{mg} / \mathrm{kg}$ feed) of zearalenone but such contamination is unusual in practice (Pier et al., 1980; Oldenburg et al., 2000). The failure of zearalenone to affect the time of luteolysis could also be related to some other factors. In sows, trophoblast cells produce large quantities of oestrogens that do not inhibit the synthesis of $\mathrm{PGF}_{2 \alpha}$, but redirect the secretion of $\mathrm{PGF}_{2 \alpha}$ from the general circulation into the uterine lumen, thus $\mathrm{PGF}_{2 \alpha}$ is not able to induce luteolysis (Bazer and Thatcher, 1977; Allen and Cooper, 1993). The equine conceptus also produces a large amount of estrogens but its role in the maternal recognition of pregnancy is not firmly established. In mares, oestrogens may not have a primary effect on corpus luteum function (Sharp, 1993). It is also possible that the toxin exposure was started too late in the cycle (day 10 after ovulation) relative to the beginning of the process leading to luteolysis. This idea is supported by data showing that daily exogenous oestrogen administration results in prolonged corpus luteum function in mares if it is started right after ovulation (Palmer, personal communication).

Finally, we conclude that the methods used in this study could not detect any adverse effect of zearalenone administered at low dose (that is similar to natural exposure) starting 10 days after ovulation on corpus luteum function, follicular development and uterine oedema in cyclic mares.

\section{Acknowledgements}

The authors wish to thank the excellent technical assistance of Ms. Erzsébet Kiss, Ms. Ibolya Simon and Mr. Béla Budai in the progesterone assays and that of Dr. Péter Kóródi in the examination of the animals. The study was partially financed by the Hungarian Scientific Research Fund (project number: OTKA T-5306).

\section{References}

Allen, W. R. and Cooper, M. J. (1993): Prostaglandins. In: McKinnon, A. O. and Voss, J. L. (eds) Equine Reproduction, Lea \& Febiger, Philadelphia. pp. 69-80.

Bazer, F. W. and Thatcher, W. W. (1977): Theory of maternal recognition of pregnancy in swine based on estrogen-controlled endocrine versus exocrine secretion of prostaglandin F2 $\alpha$ by the uterine endometrium. Prostaglandins 14, 397-402.

Berg, S. L. and Ginther, O. J. (1978): Effect of estrogens on uterine tone and life span of the corpus luteum in mares. J. Anim. Sci. 47, 203-208.

Blankenship, L. T., Dickey, J. F., Bodine, A. B. and Clemson, S. C. (1982): In vitro mycotoxin binding to bovine uterine steroid hormone receptors. Theriogenology 17, 325-331.

Bloomquist, C., Davidson, J. N. and Pearson, E. G. (1982): Zearalenone toxicosis in prepubertal dairy heifers. J. Am. Vet. Med. Assoc. 180, 164-165.

Christensen, C. M., Nelson, G. H. and Mirocha, C. J. (1965): Effect on the white rat uterus of a toxic substance isolated from Fusarium. Appl. Microbiol. 13, 653-659.

Coulombe, R. A. (1993): Biological action of mycotoxins. J. Dairy Sci. 76, 880-891. 
Csernus, V. (1982): Antibodies of high affinity and specificity for radioimmunological determination of progesterone, testosterone, estradiol-17 $\beta$ and cortisol. In: Görög, S. (ed.) Advances in Steroid Analysis I. Akadémiai Kiadó, Budapest. pp. 171-177.

Diekman, M. A. and Green, M. L. (1992): Mycotoxins and reproduction in domestic livestock. J. Anim. Sci. 70, 1615-1627.

Edwards, S., Cantley, T. C., Rottinghaus, G. E., Osweiler, G. D. and Day, B. N. (1987): The effect of zearalenone on reproduction in swine. I. The relationship between ingested zearalenone dose and anestrus in non-pregnant, sexually mature gilts. Theriogenology 28, 43-49.

Etienne, M. and Jemmali, M. (1982): Effects of zearalenone (F2) on estrous activity and reproduction in gilts. J. Anim. Sci. 55, 1-9.

Friend, D. W., Trenholm, H. L., Thompson, B. K., Hartin, K. E., Fiser, P. S., Asem, E. K. and Tsang, B. K. (1990): The reproductive efficiency of gilts fed very low levels of zearalenone. Can. J. Anim. Sci. 70, 635-645.

Ginther, O. J. (2000): Selection of the dominant follicle in cattle and horses. Anim. Reprod. Sci. 60-61, 61-79.

Huszenicza, Gy., Szigeti, G., Fekete, S., Kulcsár, M., Cseh, S., Abaváryné, M. K. and Nagy, P. (1995): Ovarian malfunctions resulting in infertility and experimental studies on some of their possible reasons in inseminated dairy cattle. A survey of recent Hungarian investigations (in Hungarian, with English abstract). Magyar Állatorvosok Lapja 50, 819-828.

Juhász, J., Nagy, P., Huszenicza, Gy., Szigeti, G., Reiczigel, J. and Kulcsár, M. (1997): Long term mycotoxin (T-2 Fusarium toxin) exposure failed to alter luteal function, follicular activity and embryo recovery in mares. Equine Vet. J., Suppl. 25, 17-21.

Kallela, K. and Ettala, E. (1984): The oestrogenic Fusarium toxin (zearalenone) in hay as a cause of early abortions in the cow. Nord. Vet. Med. 36, 305-309.

Katzenellenbogen, B. S., Katzenellenbogen, J. A. and Mordecia, D. (1979): Characterisation of the estrogenic potencies and receptor interactions of a series of fungal $\beta$-resorcylic acid lactones. Endocrinology 105, 33-40.

Koops, W. J. (1986): Multiphasic growth curve analysis. Growth 50, 169-177.

Kurtz, H. J., Nairn, M. E., Nelson, G. H., Christensen, C. M. and Mirocha, C. J. (1969): Histological changes in the genital tracts of swine fed estrogenic mycotoxin. Am. J. Vet. Res. 30, $551-556$.

Lindsay, D. G. (1985): Zeranol - A 'nature-identical' oestrogen? Food Chem. Toxicol. 23, 767-774.

Long, G. G. and Diekman, M. A. (1984): Effect of purified zearalenone on early gestation in gilts. J. Anim. Sci. 59, 1662-1670.

Long, G. G., Diekman, M. A., Tuite, J. F., Shannon, G. M. and Vesonder, R. F. (1982): Effect of Fusarium roseum corn culture containing zearalenone on early pregnancy in swine. Am. J. Vet. Res. 43, 1599-1603.

Matthews, J. N. S., Altman, D. G., Campbell, M. J. and Royston, P. (1990): Analysis of serial measurements in medical research. Brit. Med. J. 300, 230-235.

Mirocha, C. J., Harrison, J., Nichols, A. A. and McClintock, M. (1968): Detection of a fungal estrogen (F-2) in hay associated with infertility in dairy cattle. Appl. Microbiol. 16, 797-798.

Nagy, P., Solti, L., Kulcsár, M., Reiczigel, J., Huszenicza, Gy., Abaváry, K. M. and Wölfling, A. (1998): Progesterone determination in equine plasma using different immunoassays. Acta Vet. Hung. 46, 501-513.

Nett, T. M. (1993): Estrogens. In: McKinnon, A. O. and Voss, J. L. (eds) Equine Reproduction. Lea \& Febiger, Philadelphia, London. pp. 65-68.

Oldenburg, E., Valenta, H. and Sator, C. (2000): Risikoabschätzung und Vermeidungsstrategien bei der Futtermittelerzeugung. In: Dänicke, S. and Oldenburg, E. (eds) Risikofaktoren für die Fusariumtoxinbildung in Futtermitteln und Vermeidungsstrategien bei der Futtermittelerzeugung und Fütterung, Bundesforschungsanstalt für Landwirtschaft, Braunschweig, pp. $5-34$. 
Olsen, M., Malmlöf, K., Pettersson, H., Sandholm, K. and Kiessling, K.-H. (1985): Plasma and urinary levels of zearalenone and $\alpha$-zearalenol in a prepubertal gilt fed zearalenone. Acta Pharmacol. Toxicol. 56, 239-243.

Pier, A. C., Richard, J. L. and Cysewski, S. J. (1980): Implications of mycotoxins in animal disease. J. Am. Vet. Med. Assoc. 176, 719-724.

Sharp, D. C. (1993): Maternal recognition of pregnancy. In: McKinnon, A. O. and Voss, J. L. (eds) Equine Reproduction. Lea \& Febiger, Philadelphia, London. pp. 486-494.

Sirois, J., Ball, B. A. and Fortune, J. E. (1989): Patterns of growth and regression of ovarian follicles during the oestrous cycle and after hemiovariectomy in mares. Equine Vet. J., Suppl. 8, 43-48.

Smith, J. F., di Menna, M. E. and McGowan, L. T. (1990): Reproductive performance of Coopworth ewes following oral doses of zearalenone before and after mating. J. Reprod. Fertil. 89, 99-106.

Ványi, A., Glávits, R. and Molnár, T. (1995): Reproductive disorders due to F-2 and T-2 toxins in large-scale pig farms (in Hungarian, with English abstract). Magyar Állatorvosok Lapja 50, 424-430.

Ványi, A., Szemerédi, Gy., Quarini, L. and Romváry-Szailer, E. (1974): Fusariotoxicosis in a cattle herd (in Hungarian, with English abstract). Magyar Állatorvosok Lapja 29, 544-546.

Weaver, G. A., Kurtz, H. J., Behrens, J. C., Robinson, T. S., Seguin, B. E., Bates, F. Y. and Mirocha, C. J. (1986): Effect of zearalenone on the fertility of virgin dairy heifers. Am. J. Vet. Res. 47, 1395-1397.

Woodley, S. L., Burns, P. J., Douglas, R. H. and Oxender, W. D. (1979): Prolonged interovulatory interval after estradiol treatment in mares. J. Reprod. Fertil., Suppl. 27, 205-209.

Young, L. G. and King, G. J. (1986): Low concentration of zearalenone in diets of mature gilts. J. Anim. Sci. 63, 1191-1196.

Zavy, M. T., Vernon, M. W., Sharp, D. C. and Bazer, F. W. (1984): Endocrine aspects of early pregnancy in pony mares: a comparison of uterine luminal and peripheral plasma levels of steroids during the estrous cycle and early pregnancy. Endocrinology 115, 214-219. 